Jurnal Ilmiah "Kreatif" Vol. 18 No. 1, Januari 2020

"Jurnal Studi Pemikiran Pendidikan Agama Islam"

\title{
URGENSI PENDIDIKAN AGAMA BERWAWASAN MULTIKULTURAL DALAM MEMBANGUN PARADIGMA INKLUSIF PADA SEKOLAH UMUM DI KOTA BIMA
}

\author{
Oleh: \\ Irwan dan Khairudin \\ Institut Agama Islam (IAI) Muhammadiyah Bima \\ irwaniaimbima@gmail.com
}

\begin{abstract}
Abstrak:
.Pendidikan agama berwawasan multikultural sangat tepat digunakan untuk mengembangkan berbagai budaya yang baik, misalnya pluralisme, inklusifisme dan dialog yang kontinyu antar umat beragama, lebih-lebih antar umat seagama. Sehingga diharapkan seluruh masyarakat kota Bima lebih khusus para pelajar memiliki wawasan, pemahaman dan sikap bersedia menerima perbedaan, yang pada akhirnya mereka bisa menghargai antara yang satu dengan lainya.Pendidikan agama berwawasan multikultural dapat menjadi salah satu model pembelajaran yang dikaitkan dengan keragaman yang ada, baik suku, budaya, agama, bahasa, dan lain sebagainya. Hal ini dapat dijumpai di sekolahsekolah umum yang ada di Kota Bima, yang di dalam satu kelas terdiri dari berbagai siswa yang sangat beragam (suku, ras dan agama). Oleh sebab itu, pendidikan agama berwawasan multikultural sangat menarik untuk diteliti dalam rangka membangun paradigma inklusif menuju masyarakat harmoni pada sekolah umum di kota bima. Dengan adanya pendidikan agama Islam berwawasan multikultural ini diharapkan akan menjadi solusi terhadap berbagai konflik antar kelompok, golongan, mazhab, dan antar agama yang terjadi selama ini. Oleh karena itu, Pendidikan Agama berwawasan multikultural sangat penting diterapkan guna meminimalisasi dan mencegah terjadinya konflik di beberapa daerah dan kampung khususnya di Kota Bima.
\end{abstract}

Kata Kunci: Pendidikan Agama, Wawasan Multikultural, Inklusif, Masyarakat Harmoni.

\section{Pendahuluan}

Dalam banyak kasus termasuk di Kota Bima yang terjadi di kalangan umat adanya perbedaan kelompok, aliran, paham maupun organisasi telah melahirkan sikap-sikap yang tidak bersahabat bahkan cenderung mengarah kepada permusuhan. Banyak diantara umat justru berpecah belah dan saling bermusuhan. Ikatan agama yang seharusnya 
Jurnal Ilmiah "Kreatif” Vol. 18 No. 1, Januari 2020 "Jurnal Studi Pemikiran Pendidikan Agama Islam"

berfungsi mempersatukan, apapun kelompuk, aliran, paham, oraganisasi bahkan agamanya tidak dapat berfungsi secara maksimal, antar masyarakat justru saling menciptakan permusuhan, ketika seseorang semakin taat dengan ajaran kelompok atau aliran yang dianutnya, bukan sikap baik dan ramah terhadap kelompok atau aliran lain yang muncul darinya, akan tetapi justru semakin bertambah tajam rasa tidak suka dengan yang lain. Perbedaan pemahaman dan pendapat tentang persoalan agama yang sangat wajar terjadi justru malah dijadikan alasan untuk saling membunuh dan melegalkan kebencian terhadap kelompok lain yang pada hakekatnya adalah saudara seagama.

Pada skala Nasional, ketegangan, kekerasan serta konflik yang terkait dengan isu-isu keagamaan belakangan semakin merajalela, perusakan dan pembakaran rumah-rumah ibadah; sampai dengan sejumlah peristiwa pemboman dengan keyakinan jihad. Tanda-tanda bahwa gejala ini akan segera berhenti belum tampak jelas hingga saat ini di hadapan kita. Prilaku segelintir orang tersebut dapat dipandang sebagai sikap yang mencerminkan sikap cacat etika dan cacat moral dalam kehidupan berbangsa dan bernegara. Tetapi, ironisnya apa yang mereka lakukan selalu dikaitkan atas nama agama yang suci. Bahkan belakangan ini sikap tenggang rasa, solidaritas sosial, toleransi terhadap perbedaan suku, etnis, dan toleransi terhadap perbedaan agama semakin menurun dan menipis. ${ }^{1}$ Di kota Bima khususnya, kasus-kasus yang muncul misalnya penggerbekan terduga teroris, perkelahian antar pelajar serta perkelahian antar warga hampir-hampir membuat miris hati setiap orang, bahkan Bima sempat dicap dengan istilah "Daerah zona Merah" daerah rawan konflik antar agama, antar kampung dan lain-lain

Fenomena di atas menunjukkan bahwa keragaman dan multikultikultural belum bisa dikelola secara benar, terutama dalam lembaga pendidikan formal. Kalau hal ini dibiarkan tentunya akan menjadi ancaman bagi keutuhan bangsa dan negara. Hal ini juga menunjukkan adanya kesenjangan antara idealitas agama (das sollen), sebagai ajaran dan pesan-pesan suci Tuhan dengan realitas empirik yang terjadi dalam masyarakat (das sein).Padahal secara historis, bangsa

\footnotetext{
${ }^{1}$ Lihat hasil jajak pendapat yang dilakukan oleh Kompas edisi Senin 11 Agustus 2008.
} 
Jurnal Ilmiah "Kreatif" Vol. 18 No. 1, Januari 2020 "Jurnal Studi Pemikiran Pendidikan Agama Islam"

Indonesia telah memiliki modal nasionalitas yang amat berharga. ${ }^{2}$ Kemajemukan dan multikulturalitas mengisyaratkan adanya perbedaan.Bila dikelola secara benar kemajemukan dan multikulturalitas menghasilkan kekuatan positif bagi pembangunan bangsa.Sebaliknya, bila tidak dikelola secara benar, kemajemukan dan multikulturalitas bisa menjadi faktor destruktif dan menimbulkan bencana yang dahsyat. Konflik dan kekerasan sosial yang sering terjadi antara kelompok masyarakat merupakan bagian dari kemajemukan dan multikulturalitas yang tidak bisa dikelola dengan baik. ${ }^{3}$ Oleh sebab itu, peranan pendidikan agama dapat menjadi sumber inspirasi etika, moral, dan spiritual bagi kehidupan peserta didik dalam menghadapi realitas kehidupannya.Namun, peranan yang ideal dan mulai tersebut dalam tataran pelaksanaannya seringkali menghadapi berbagai permasalahan serius.Salah satu kritik yang sering muncul, bahwa pada umumnya pendidikan agama selama ini belum melaksanakan fungsi utamanya secara maksimal, yaitu membentuk prilaku peserta didik yang memiliki etika, moral, spiritualitas yang baik. ${ }^{4}$

Paradigma Pendidikan Agama dengan berwawasan multikulturalme tidak saja mengandaikan hadirnya keanekaragaman elemen sosial budaya tetapi juga hadirnya proses amalgamisasi/peleburan. Proses amalgamisasi ini bukan dalam pengertian penciptaan identitas tunggal melalui penyeragaman yang represif-inferior, tetapi kerelaan saling melebur tanpa harus menghilangkan identitas-identitas sosial masing-masing. Paradigma multikulturalisme sebagai basis bagi pendidikan Islam berarti meniscayakan pemahaman bahwa elemen-elemen sosial budaya harus bersifat inklusif untuk membuka diri terhadap elemen-elemen lain di

${ }^{2}$ Abdurrahman Wahid dkk, Quo Vadis Pendidikan Islam Pembacaan Realitas Pendidikan Islam, Sosial dan Keagamaan (Malang, UIN Malang Press, 2006), hal . 190-191.

${ }^{3}$ Tobroni dkk, Pendidikan Kewarganegaraan Demokrasi, HAM, Civil Society, dan Multikulturalisme, (Yogyakarta, PuSaPoM. 2007), hal. 279.

${ }^{4}$ Soleh Subagja, Pendekatan Multikultural dalam Pendidikan Agama Islam (Malang, 2008), hal. 1. 
Jurnal Ilmiah "Kreatif" Vol. 18 No. 1, Januari 2020 "Jurnal Studi Pemikiran Pendidikan Agama Islam"

luar, dan berani berkompromi dengan yang lain. ${ }^{5}$ Pendidikan multikultural berusaha membangun pemahaman terhadap setiap insan manusia terhadap nilai-nilai universal yang ada dalam agama-agama sebagai modal dasar yang utama. Maka, tujuan utama pendidikan multikultural adalah pemahaman mereka dapat menyadari meskipun masing-masing agama mempunyai bentuk yang berbeda-beda, agamaagama itu mempunyai substansi religiusitas yang sama yaitu mengandung ajaran tentang "nilai-nilai universal. ${ }^{6}$ Terjadinya paradigma keberagamaan yang eksklusif selama ini di masyarakat dan di sekolah dapat menyebabkan terjadinya berbagai konflik baik antar umat beragama dan juga interen Islam, karena realitasnya di sekolah hanya mengajarkan atau menanamkan bahkan mendoktrin keagamaan atau materi secara tekstua, literal, dan ritual, tidak menyentuh hati atau bahkan tidak berkaitan dengan masalah-masalah kontekstual dan sosial yang mampu menumbuhkan sifat yang humanis, pluralis, demokratis, dan lain sebagainya. ${ }^{7}$

Dengan adanya pendidikan agama Islam berwawasan multikultural ini diharapkan akan menjadi solusi terhadap berbagai konflik antar kelompok, golongan, mazhab, dan antar agama yang terjadi selama ini.Oleh karena itu, Pendidikan Agama berwawasan multikultural sangat penting diterapkan guna meminimalisasi dan mencegah terjadinya konflik di beberapa daerah. Melalui pendidikan Agama berwawasan multikultural, sikap dan mindset (pemikiran) siswa akan lebih terbuka untuk menghargai keberagaman. "Dengan pengembangan model pendidikan Agama berwawasan multikultural diharapkan mampu menjadi salah satu metode efektif meredam konflik. Selain itu, pendidikan agama multikultural bisa menanamkan sekaligus mengubah pemikiran peserta didik untuk benar-benar tulus menghargai keberagaman etnis, golongan, ras, dan agama. Pendidikan agama

${ }^{5}$ Zakiyuddin Baidhawy, Membangun Harmoni dan Perdamaian Melalui Pendidikan Agama Berwawasan Multikultural (Jakarta, Departemen Agama, 2008), hal. 3 .

${ }^{6}$ Titin Nur Afidah, Konsep dan Paradigma Pendidikan Multikultural, (Malang, UMM, 2006), hal. 4.

${ }^{7}$ Zakiyuddin Baidhawy, Membangun Harmoni dan Perdamaian Melalui Pendidikan Agama Berwawasan Multikultural (Jakarta, Departemen Agama, 2008), hal. 3 . 
Jurnal I lmiah "Kreatif" Vol. 18 No. 1, Januari 2020 "Jurnal Studi Pemikiran Pendidikan Agama Islam"

berwawasan multikultural adalah salah satu model pembelajaran yang dikaitkan dengan keragaman yang ada, baik suku, budaya, agama, bahasa, dialek dan lain sebagainya.Hal ini dapat dijumpai di sekolahsekolah umum yang ada di Kota Bima, yang di dalam satu kelas terdiri dari berbagai siswa yang sangat beragam (suku, ras dan agama).Oleh sebab itu, pendidikan agama berwawasan multikultural sangat menarik untuk diteliti yang kemudian dikemas dalam judul "Urgensi Pendidikan Agama Berwawasan Multikultural Dalam Membangun Paradigma Inklusif Pada Sekolah Umum Di Kota Bima”.

\section{Hasil Penelitian Dan Pembahasan}

\section{Urgensi Pendidikan Agama Berwawasan Multikultural Dalam Membangun Paradigma Inklusif Pada Sekolah Umum Di Kota Bima}

Dipahami bersama bahwa agama seharusnya dapat menjadi pendorong bagi umat manusia untuk selalu menegakkan kebaikan dan perdamaian serta meningkatkan kesejahteraan bagi umat manusia di bumi ini. Sayangnya, dalam kehidupan yang sebenarnya, ada sebahagian atau segolongan orang menjadikan agama justru seakan-akan menjadi salah satu penyebab terjadinya kekerasan dan kehancuran umat manusia.Multikultural atau pluralitasmerupakan sebuah sistem nilai yang memandang secara positif terhadap kemajemukan itu sendiri, dengan menerimanya sebagai kenyataan dan berbuat sebaik mungkin berdasarkan kenyataan itu.Kemajemukan agama atau pluralitas umat manusia sesungguhnya kenyataan yang tak terbantahkan yang telah menjadi sebuah aturan dan kehendak Tuhan (sunnatullah) yang tidak berubah, sehingga juga tidak mungkin dilawan atau dipungkiri. Islam adalah agama yang kitab sucinya dengan tegas mengakui hak agamaagama lain, kecuali berdasarkan paganisme atau syirik, untuk hidup dan menjalankan ajaran masing-masing dengan penuh kesungguhan tanpa memaksakan kepada agama lain.

Problem yang paling utama yang kita hadapi dalam masyarakat majemuk adalah interpretasi (pemaknaan) manusia akan teks suci yang dipercaya sebagai ungkapan langsung dari Tuhan kepada manusia sementara dalam kerangka kerjanya, tidak ada yang seragam terhadap suatu hal, pastilah akan ada perbadaan yang disebabkan banyak hal. 
Jurnal Ilmiah "Kreatif” Vol. 18 No. 1, Januari 2020 "Jurnal Studi Pemikiran Pendidikan Agama Islam"

Untuk mengantisipasi terjadinya berbagai ancaman intoleran maupun hal lainnya yang tidak diinginkan, lembaga pendidikan merupakan sarana yang efektif dalam meminimalisir bahkan menghindarkan hal tersebut, pendidikan agama berwawasan multikultural merupakan salah satu solusi tepat untuk menyelesaikan semua permasalahan tersebut apabila benar-benar dilaksanakan dengan maksimal. Sesungguhnya ajaran Islam sangat terbuka terhadap kemajemukan agama, budaya dan lain sebagainya, namun dalam pemaknaan ajaran agama tersebut muncul berbagai macam respon (baik positif maupun negatif) terhadap adanya kemajemukan perbedaan itu. Dalam penelitian ini peneliti melakukan wawancara dengan guru-guru pendidikan agama Islam (di SMAN 1 dan SMAN 2 Kota Bima) dan juga guru agama Kristen di Kota Bima sebagai studi perbandingan, tentang wawasan multikultural dalam pendidikan agama, sebagaimana diungkapkan di bawah ini:

Harus diakui bahwa di Indonesia ada beberapa macam agama (Islam, Kristen Katolik dan Protestan) dan aliran kepercayaan bahkan budaya, etnis suku dan ras yang sudah diatur oleh UUD 1945 pasal 1 ayat 29, karena negara kita juga berdasarkan pancasila dan UUD, mau tidak mau kita terima sebagai sebuah kenyataan, yang penting kita bisa saling menghargai dan menghormati. Sabagai guru agama, proses transformasi pengetahuan dan penananaman nilai-nilai agama harus dipadukan dengan nilai-nilai multikultural supaya para peserta didik tidak salah memahami dan menyikapi berbagai perbedaan yang ada. Ketika seperti itu kita lakukan niscaya semuanya tidak akan ada yang merasa dirugikan atau merasa tidak dihargai. Hal ini dapat dijumpai ketika saya mengajar seluruh anak-anak yang nonmuslim juga senang mengikuti proses pembelajaran PAI. Keseriusan kita dalam memahami semua perbedaan melalui pendalaman wawasan multikultural dalam pembelajaran PAI harus menjadi perioritas. ${ }^{8}$

Ajaran Islam tidak pernah memaksakan kepada penganut agama lain untuk memeluk agama Islam, karena realitas di masyarakat kita adalah plural (majemuk), kalau masing-masing penganut agama memaksakan kepada penganut agama lain maka yang terjadi adalah

\footnotetext{
${ }^{8}$ Hasil wawancara dengan BapakDrs, Ishaka H.Ab Guru Pendidikan Agama Islam SMAN 1 Kota Bima, Hari Rabu, 21 Oktober 2016.
} 
Jurnal Ilmiah "Kreatif” Vol. 18 No. 1, Januari 2020 "Jurnal Studi Pemikiran Pendidikan Agama Islam"

konflik yang memang tidak bisa dihindari. Lembaga pendidikan sebagai benteng utama dalam menjaga keutuhan bangsa dan tanah air harus benar-benar serius menginternalisasikan nilai-nilai multikultural jangan sampai hal tersebut dianggap tabu, karena hampir setiap konflik yang terjadi di Bima (antar kampung maupun antar organisasi masyarakat) diawali oleh perkelahian atau cekcok anak-anak sekolah (peserta didik) yang memang tidak bisa menerima setiap perbedaan baik berupa pendapat, pemahaman maupun lainnya. ${ }^{9}$

Kemajemukan agama dan lain sebagainya yang ada di Indonesia adalah kenyataan yang perlu kita jaga bersama, kita sikapi dengan bijak, dan dewasa, saling menghormati, menghargai tanpa harus memaksakannya kepada orang lain. Masing-masing pemeluk agama akan merasa bangga dengan agamanya, hal ini jangan sampai menjadi bumerang satu sama lain dan masing-masing agama pengen menunjukkan diri yang terbaik, ukuran baik sebuah agama bukan pada banyak atau sedikitnya simbol agama (mesjid, gereja, vihara) yang dimiliki, tapi bagaimana memahami substansi dari masing-masing agama itu sendiri, karena secara umum semua agama memiliki misi yang sama. Kalau saja masing-masing masyarakat memahami substansi dari masing-masing agamanya, tidak akan terjadi yang namanya konflik, karena setiap agama tidak pernah mengajarkan kekerasan justru yang diajarkan adalah kedamaian. ${ }^{10}$ Lebih lanjut Ibu Marlina menceritakan pengalamannya dalam mengahadapi keluarganya yang majemuk.

Saya hidup dalam lingkungan keluarga yang majemuk, dalam keluarga juga memiliki yayasan An-Nur, yang menjadi ketua saya (agama Kristen), bagi saya dan keluarga perbedaan agama tidak menjadi masalah buat kami, yang dalam bersikap dan berprilaku sesuai dengan keyakinan masing-masing tanpa harus memaksakan kepada orang lain dan justru hidup ini akan terasa indah karena adanya perbedaan, semua tergantung pada kita memaknai substansi dari ajaran agama masing-masing.

\footnotetext{
${ }^{9}$ Hasil wawancara dengan Bapak Muhilli, S.Pd.I Guru Pendidikan Agama Islam SMAN2 Kota Bima, Hari Kamis, 20Oktober 2016.

${ }^{10}$ Hasil wawancara dengan Ibu Marlina, S.Pd guru agama Kristen SMAN 1Kota Bima, Hari Rabu, 20 Oktober 2016.
} 
Jurnal Ilmiah "Kreatif" Vol. 18 No. 1, Januari 2020 "Jurnal Studi Pemikiran Pendidikan Agama Islam"

Pada dasarnya Islam tidak bertentangan dengan adanya kemajemukan atau multikultural. Bahkan Islam sejalan dengan multikultural.Ajaran-ajaran Islam banyak menjelaskan tentang pentingnya menghargai perbedaan dan saling menghormati terhadap perbedaan tersebut. Jika kita renungkan banyak sekali firman suci yang diturunkan Tuhan kepada manusia untuk memperoleh beberapa penegasan, di antaranya: (1) multikulturalisme masyarakat manusia merupakan kehendak dan keputusan Tuhan; (2) multikulturalisme itu membuat manusia senantiasa berselisih pendapat dengan sesamanya, namun orang yang mendapat rahmat Tuhan tidak akan mudah berselisih karena sebagaimana disebutkan di atas, ia akan bersikap penuh pengertian, saling menghargai, lemah lembut, dan rendah hati kepada sesamanya.

Menurut Ibu Marlina, ada beberapa faktor kenapa masyarakat selama ini memiliki punya pola yang eksklusif terhadap kemajemukan agama, budaya, suku dan ras yang ada.

1. faktor pendidikan, pendidikan memiliki peranan penting dalam membentuk pola pikir manusia. Karena pendidikan bersentuhan langsung pada ranah kognitif, afektif dan psikomotorik, semakin tinggi tingkat pendidikan suatu masyarakat, maka semakin bijak pula dalam bertindak dan merespon segala kemajemukan, terutama kemajemukan agama.

2. faktor usia, ada dua kemungkinan yang ada ketika usia manusia semakin bertambah, pertama, tingkat kedewasaan berpikirnya semakin luas dalam menganalisa satu permasalahan termasuk dalam merespon kemajemukan agama; kedua, pola pikirnya yang semakin sempit dalam menganalisa satu permasalahan, termasuk dalam merespon kemajemukan agama. Di lingkungan saya mengajar, awalnya kehadiran saya agak susahditerima oleh guruguru yang sudah agak umur. Saya maklumi karena faktor pengetahuan juga.

3. faktor lingkungan, pola pikir manusia, kadang dibentuk oleh lingkungan di mana dia tinggal. Orang yang terbiasa hidup di lingkungan yang majemuk, dia lebih cenderung memiliki pola pikir yang lebih luas dan menerima segala perbedaan yang ada. Lain halnya dengan orang yang hidup di lingkungan yang tidak majemuk. 
Jurnal Ilmiah "Kreatif” Vol. 18 No. 1, Januari 2020 "Jurnal Studi Pemikiran Pendidikan Agama Islam"

Dari tiga faktor tersebut maka sebagai pendidik saya sangat sepakat apabila pendidikan agama yang berwawasan multikultural sangan urgen bahkan wajib diterapkan atau diinternalisasikan dalam setiap proses pembelajaran, supaya kita bisa mewariskan generasigenerasi yang bisa hidup berdampingan satu sama lainnya. Bapak Drs. Safrudin $^{11}$ pada beberapa kesempatan diwawancarai mengemukakan. Meskipun secara riil pendidikan agama berwawasan multikultural belum kami masukkan dalam kurikulum, akan tetapi nilai-nilai multikultural di jenjang pendidikan yang saya pimpin (SMAN 1 Kota Bima) harus dilaksanakan. Hal ini sangatlah penting mengingat kasuskasus yang akhir-akhir ini terjadi di kota Bima yang sempat menimbulkan stigma negatif dari berbagai kalangan terutama dari pihak Polri (Densus 88) pada derah kami. Hal ini memicu semangat kami untuk senantiasa melakukan upaya deradikalisasi melalui kegiatankegiatan seminar yang kami adakan, bekerjasama dengan berbagai pihak baik dari BNPT, POLRES, DIKPORA, MUI dan lain sebagainya. Yang terpenting dari itu semua adalah bagaimana setiap guru (pendidik) terutama guru pendidikan agama diharapkan untuk intens menanamkan nilai-nilai multikultural dikalangan peserta didik agar tercipta kehidupan masyarakat yang rukun, aman, tenteram dan harmonis. Harapan saya, seluruh lembaga pendidikan yang ada mewajibkan nilainilai multikultural ditanamkan dalam jiwa seluruh pendidik, peserta didik bahkan seluruh elemen masyarakat. Senada dengan hal di atas, Bapak Imran ${ }^{12}$ juga dalam berbagai kesempatan diwawancara mengemukakan;

Saya termasuk orang yang sangat alergi terhadap praktek intoleran, mengapa demikian.? Kita sepakat bahwa Negara kita ini bukanlah negara yang hanya memiliki satu agama, satu golongan, satu budaya, etnis dan satu suku, melainkan multi seluruhnya. Lantas mengapa kita harus saling mengklaim, menindas, bahkan merampas hak dan kebebasan yang lainnya.? Ketika kita menyadari sepenuh hati akan hal tersebut maka dengan sendirinya kita akan mudah memahami berbagai perbedaan yang ada. Bukankah dalam ajaran agama, khususnya

\footnotetext{
${ }^{11}$ Hasil wawancara dengan kepala SMAN 1 Kota Bima Bapak Drs. Syafrudin, pada tanggal 15 November 2016.

${ }^{12}$ Hasil wawancara dengan Kepala SMAN 2 Kota Bima Bapak Imran, S. Pd, pada tangal 16 November 2016.
} 
Jurnal I lmiah "Kreatif" Vol. 18 No. 1, Januari 2020 "Jurnal Studi Pemikiran Pendidikan Agama Islam"

dalam ajaran Islam dianjurkan untuk bertoleransi, saling menghormati dan menghargai satu dengan lainnya. Mengapa harus terjadi pembunuhan, pembantaian, pengeboman mengatas namakan agama.? Padahal dalam ajaran agama, jangankan membunuh manusia membunuh binatang saja yang tanpa hak merupakan dosa besar. Hal inilah yang perlu ditanamkan dalam jiwa seluruh masyarakat terutama pendidik dan peserta didik. Di sekolah saya, saya menyaring guru-guru yang akan mengajar jangan sampai ada guru-guru yang memiliki pemahaman yang fanatik buta, saya tidak segan-segan untuk meluruskan atau menegurnya karena ini tanggung jawab kita semua. Kalau dibiarkan maka akan sangat berbahaya bagi kelangsungan peradaban hidup masyarakat yang heterogen ini. Oleh karena itu, pendidikan agama berwawasan multikultural wajib dilaksanakan di lembaga yang saya pimpin ini, agar peserta didik calon-calon generasi penerus kita ini dapat hidup berdampingan dengan paradigma yang inklusif yang dapat menghargai segala apapun yang ada dan ia hadapi.

Untuk memahami akan hal di atas, ada beberapa prinsip pokok yang perlu dikemukakan tentang kemajemukan agama: (1) Islam adalah agama yang bersifat universal, Islam bukan diperuntukkan bagi salah satu suku, bangsa, etnis, atau golongan tertentu, melainkan sebagai rahmatan lil 'alamin; (2) Islam menghargai agama-agama dan kepercayaan agama lain, Islam mengajarkan tidak ada paksaan dalam agama; (3) Islam juga merupakan agama yang terbuka untuk diuji kebenarannya; (4) Islam juga menegaskan bahwa keanekaragaman dalam kehidupan umat manusia adalah alamiah, perbedaan itu mulai dari jenis kelamin, suku dan bangsa yang beraneka ragam, agar saling mengenal; (5) Islam memiliki sejarah yang cukup jelas terkait dengan kehidupan yang mejemuk sebagaimana yang ditunjukkan oleh Rasulullah sendiri ketika membangun masyarakat madani di Madinah, sebagai sebuah Negara. Madinah sudah mengakui, menghargai dn mengakomodasi berbagai etnik dan berbagai golongan. Semua warga Negara menikmati hak hidup dan dilingdungi oleh undang-undang, sebagaimana yang diatur dalam piagam Madinah.Prinsip-prinsip dasar seperti ini perlu dijadikan rujukan di tengah-tengah kehidupan majemuk sekarang.

Pendidikan merupakan agen perubahan dalam suatu masyarakat yang tidak terlepas dari budaya masyarakat tersebut. Nilai-nilai, 
Jurnal Ilmiah "Kreatif” Vol. 18 No. 1, Januari 2020 "Jurnal Studi Pemikiran Pendidikan Agama Islam"

pandangan dan norma yang dikembangkan merupakan integrasi dari budaya di mana pendidikan tersebut dilaksanakan, yang kemudian ditanamkan kepada peserta didik pendidikan merupakan media yang tepat bagi usaha pelestarian dan penanaman nilai-nilai atau pandangan, demikian juga penanaman kesadaran terhadap adanya kemajemukan (agama, budaya, suku) pada masyarakat. Dalam lingkungan sekolah terutama di kelas kita selalu mengajarkan kepada anak-anak untuk saling menghargai dan menghormati, perbedaan agama, atau suku bukan penghalang bagi kita untuk tetap bersatu padu. Diharapkan apa yang kita ajarkan ini, ketika anak-anak berada dalam lingkungan yang majemuk atau ke depan mereka sudah siap dan bisa menerapkannya. ${ }^{13}$ Tidak hanya sekedar materi tentang akidah atau ibadah yang kita sampaikan, ketika proses belajar mengajar pendidikan agama Islam sedang berlangsung, kami menyampaikan kepada anak-anak untuk selalu saling menghormati dan menghargai satu sama lain, walaupun berbeda suku, budaya, maupun agama. Karena dalam pelajaran pendidikan agama Islam ada juga materi yang berkaitan dengan tasamuh atau toleransi, sikap saling menghargai dan menghormati orang lain dalam melaksanakan hak-haknya. Kita tidak boleh memandang rendah atau meremehkan, suku, budaya, agama lain, apalagi sikap menghina, membenci dan memusuhinya, karena toleransi juga bagian dari ajaran Islam.Ini hal-hal yang perlu kita tanamkan kepada anak didik kami di sini. ${ }^{14}$ Tidak menjadi masalah mereka (siswa-siswa non Islam) ikut pelajaran pendidikan agama Islam, asalkan bagaimana kita guru bisa menjelaskan dengan baik terhadap materi yang ada dalam kurikulum. Perbedaan itu akan terasa indah bila dalam proses pembelajarn itu kita ciptakan suasana yang harmonis dan saling menghargai tanpa kita menyinggung soal suku, budaya dan agama lain. ${ }^{15}$

Inilah upaya-upaya yang kami lakukan di sini, paling tidak kita mengajarkan kepada siswa-siswi untuk saling menghargai, dan

\footnotetext{
${ }^{13}$ Hasil wawancara dengan Ibu Marlina dan Bapak Ishaka.

${ }^{14}$ Hasil wawancara dengan BapakSalahuddin, M.Pd Salah satu guru pendidikan agama Islam di SMAN 2 Kota Bima, pada hari Jum'at, tanggal 21 Oktober 2016.

${ }^{15}$ Hasil wawancara dengan Ibu Nurbaya, S.Pd.Isalah satu guru PAI SMAN 1 Kota Bima, pada tanggal 20 Oktober 2016.
} 
Jurnal Ilmiah "Kreatif” Vol. 18 No. 1, Januari 2020 "Jurnal Studi Pemikiran Pendidikan Agama Islam"

menghormati baik dalam bentuk kegiatan keagamaan (di luar kelas) maupun pola pengajarannya di dalam kelas. Harapannya ke depan ketika siswa-siswi bergaul dengan lingkungan yang lebih luas mereka sudah terbiasa dengan kondisi seperti itu. Paling tidak itulah langkah awal yang kami lakukan di sini. ${ }^{16}$ Dari penjelasan tentang perlunya memahami kemajemukan segala hal di atas, diharapkan mampu mendorong umat manusia terutama masyarakat kota Bima untuk selalu menegakkan perdamaian dan meningkatkan kesejahteraan bagi seluruh umat manusia di muka bumi ini. Maka sangat perlu untuk membangun upaya-upaya prefentif agar pertentangan-pertentangan tidak akan terulang lagi di masa mendatang, perlulah kiranya mengintensifkan forum-forum dialog antar umat beragama dan aliran kepercayaan untuk membangun pemahaman keagamaan yang lebih pluralis dan inklusif, serta memberikan pendidikan yang pluralis dan toleransi beragama. Berkaitan dengan hal ini, maka penting bagi lembaga pendidikan dalam masyarakat yang multikultural untuk mengajarkan perdamaian dan resolusi konflik seperti yang ada dalam pendidikan multikultural.Karena bila kita cermati berbagai kasus terjadinya konflik agama selama ini, salah satu faktor penyebabnya adalah adanya paradigma keberagamaan masyarakat yang bersifat eksklusif.Karena itu, diperlukan langkahlangkah preventif untuk mencegah berkembangnya paradigma tersebut, yaitu dengan membangun pemahaman keberagamaan yang lebih inklusif, humanis, dialogis, kontekstual melalui pendidikan. Untuk menanamkan dan mengimplementasikan nilai-nilai keagamaan yang bersifat inklusif diperlukan guru yang mempunyai wawasan multikultural, karena ia merupakan target dari strategi tersebut. Apabila seorang guru memiliki paradigma keberagamaan yang inklusif dan moderat, maka ia juga akan mampu mengajarkan dan mengimplementasikan nilai-nilai keberagamaan tersebut terhadap siswa di sekolah.

\section{Implikasi Pendidikan Agama Berwawasan Multikultural Dalam Membangun Paradigma Inklusif Pada Sekolah Umum Di Kota Bima.}

\footnotetext{
${ }^{16}$ Hasil wawancara dengan Bapak kepala sekolah SMAN1 Kota Bima, pada tanggal 21Oktober 2016.
} 
Jurnal Ilmiah "Kreatif” Vol. 18 No. 1, Januari 2020 "Jurnal Studi Pemikiran Pendidikan Agama Islam"

Dalam proses belajar mengajar seharusnya pendidik selalu memperhatikan individu peserta didik serta menghormati martabat dan kebebasan dalam mengeluarkan pendapat dan menetapkan pendiriannya, sehingga bagi peserta didik, belajar merupakan hal sangat menyenangkan dan sekaligus mendorong kepribadiannya berkembang secara optimal. Sedangkan bagi guru, proses pembalajaran merupakan tanggungjawab dan kewajiban yang bernilai ibadah di hadapan Tuhan yang Maha Esa. Guru merupakan faktor yang penting dalam mengimplementasikan nilai-nilai keagamaan yang inklusif dan moderat di sekolah. Guru mempunyai peran penting dalam mengajarkan pendidikan agama Islam berwawasan multikultural, karena ia merupakan target dari strategi tersebut. Apabila seorang guru memiliki paradigma keberagamaan yang inklusif dan moderat, maka ia juga akan mampu mengajarkan dan mengimplementasikan nilai-nilai keberagamaan tersebut terhadap siswa di sekolah. Mengenai hal tersebut peneliti melakukan wawancara dengan salah satu guru pendidikan agama Islam, dan hasilnya:

Walaupun di dalam materi pendidikan agama Islam ada doktrindoktrin beragama, tinggal bagaimana kita (guru) menjelaskan dengan metode (cara) yang tepat, dan mudah dipahami oleh anak-anak. Misalnya ada doktrin agama Islam, agama yang terbaik sedangkan agama lain di luar Islam tidak ada yang selamat, atau semuanya masuk neraka. Hal-hal tersebut kalau kita tidak menjelaskan dengan baik, kita takutnya anak-anak yang beragama lain akan mudah tersinggung, dan selama pelajaran pendidikan agama Islam selama saya ngajar tidak ada masalah, buktinya anak-anak non muslim masih banyak yang ikut pelajaran pendidikan agama Islam. Oleh karena itu diperlukan pemahaman yang agak luas, penguasaan metode yang banyak sehingga anak-anak lebih mudah memahami apa yang kita sampaikan. ${ }^{17}$

Lebih lanjut Bapak Muhilli juga mengatakan guru sebagai pelaksana di lapangan memiliki peran yang sangat strategis dalam menyelesaikan persoalan-persoalan kebangsaan yang sering dikaitkan dengan dunia pendidikan. Dengan demikian, yang perlu diperhatikan oleh semua pihak adalah optimalisasi peran guru dalam proses belajar

${ }^{17}$ Hasil wawancara dengan Bapak Muhilli, S.Pd.I salah satu guru pendidikan agama Islam pada hari sabtu, tanggal 05 November 2016. 
Jurnal Ilmiah "Kreatif” Vol. 18 No. 1, Januari 2020 "Jurnal Studi Pemikiran Pendidikan Agama Islam"

mengajar di kelas yang perlu ditingkatkan. Dengan demikian guru diharapkan memiliki keluasan dalam mengelola kelas dengan metode yang selalu benar. Terkait dengan hal tersebut, peneliti juga melakukan wawancara dengan kepala sekolah, dan hasilnya: ${ }^{18}$

Kita di sini memberikan keluasan kepada guru-guru pendidikan agama Islam untuk merancang program-program baik yang intra kurikuler yang tidak diatur dalam kurikulum, maupun kegiatan ekstra kurikuler.Kita sepenuhnya menyerahkan kepada mereka untuk melakukan kegiatan keagamaan, demi kepentingan anakanak itu sendiri. ${ }^{19}$

Penanaman doktrin agama dan metode pembelajaran yang dipakai selama ini, saya lihat kurang atau bahkan tidak dipakai lagi, karena lebih bersifat diktator atau dalam bahasanya Paulo Freira pengajaran gaya bank, anak-anak tidak diberi ruang untuk mendialogkan atau mengkritisi setiap materi yang diajarkan, anak-anak hanya sebatas menerima. Cara-cara lama seperti itu tidak cocok lagi untuk diajarkan pada masyarakat yang majemuk sekarang, saya lebih cenderung pada model bermain, dialog, kontekstual dan sebelum saya menetapkan metode pembelajaran dan penanaman doktrin beragama terlebih dahulu saya mempelajari bagaimana prilaku siswa. ${ }^{20}$

Menumbuhkan kesadaran akan keragaman dalam beragama bukanlah hal mudah, mengingat pemahaman keberagamaan umat tengah diuji dengan dunia informasi yang memberi kemudahan pengaksesan yang nyaris tanpa batas, agama yang tidak hanya dipahami secara menyeluruh, hanya secara parsial atau setengah-setengah, pada akhirnya hanya menimbulkan perpecahan antar umat, baik seagama atau antar agama, terbentuknya agama baru, aliran sesat, serta kekerasan atas nama agama. Untuk itu diperlukan format baru dalam pendidikan agama Islam yakni dengan pendidikan agama Islam berawasan multikultural. Pendidikan agama yang berwawasan multikultural mengusung pendekatan dialogis untuk menanamkan kesadaran hidup bersama dalam keragaman dan perbedaan, pendidikan ini dibangun atas

\footnotetext{
${ }^{18}$ Hasil wawancara dengan Bapak Salahuddin, S.Ag, M.Pd, salah satu guru pendidikan agama Islam pada hari sabtu, tanggal 05 November 2016.

${ }^{19}$ Hasil wawancara dengan kepala sekolah SMAN 2 Kota Bima, Bapak Imran, S.Pd, Pada hari Selasa, tanggal 08November 2016.

${ }^{20}$ Hasil wawancara dengan Ibu Marlina.
} 
Jurnal Ilmiah "Kreatif" Vol. 18 No. 1, Januari 2020 "Jurnal Studi Pemikiran Pendidikan Agama Islam"

spirit relasi kesetaraan dan kesederajatan, saling percaya, saling memahami dan menghargai persamaan, perbedaan dan keunikan. Ini merupakan inovasi yang reformasi, yang integral, dan komprehensif dalam muatan pendidikan agama-agama yang bebas prasangka, resisme, bias dan stereotip. Pendidikan agama berwawasan multikultural memberi pengakuan akan pluralitas, sarana belajar untuk perjumpaan lintas batas, dan mentransformasi indoktrinasi menuju dialog.

\section{Penutup}

Pendidikan agama berwawasan multikultural merupakan sebuah model pendidikan agama yang berusaha mengajak dan memahamkan nilai-nilai keragaman dalam bingkai persatuan sebagai sebuah kenyataan yang perlu dijaga bersama, disikapi dengan bijak dan dewasa, saling menghormati, menghargai tanpa harus memaksakannya apapun kepada orang lain. Pendekatan yang dipakai dalam pendidikan agama yang berwawasan multikultural mengusung pendekatan dialogis untuk menanamkan kesadaran hidup bersama dalam keragaman dan perbedaan, guru pendidikan agama perlu menanamkan dan membangun pola pikir dan menjadi spirit relasi kesetaraan dan kesederajatan, saling percaya, saling memahami dan menghargai persamaan, perbedaan dan keunikan. Terbentuknya paradigma seperti itu sangat ditentukan oleh beberapa faktor, tingkat pendidikan, usia dan lingkungan (sekolah) di mana dia berada. Dan pada akhirnya, pendidikan agama diharapkan akan menjadi sumber inspirasi dalam membentuk karakter masyarakat, sehingga akan terwujud masyarakat yang memiliki mind set (pola pikir): belajar hidup dalam perbedaan, membangun saling percaya, memelihara saling pengertian, menjunjung sikap saling menghargai, terbuka dalam berpikir, apresiasi dan interpedensi, resolusi konflik dan rekonsiliasi nirkekerasan.

\section{DAFTAR PUSTAKA}

Afidah,Titin Nur. Konsep dan Paradigma Pendidikan Multikultural. Malang, UMM, 2006.

Jajak pendapat yang dilakukan oleh Kompas edisi Senin 11 Agustus 2008. 
Jurnal Ilmiah "Kreatif” Vol. 18 No. 1, Januari 2020

"Jurnal Studi Pemikiran Pendidikan Agama Islam"

Liliweri, Alo. Prasangka dan Konflik Komunikasi Lintas Budaya Masyarakat Multikultur cet 1. Yogyakarata: LKIS, 2005.

Maslikhah. Quo Vadis Pendidikan Multikultural Rekonstruksi Sistem Pendidikan Berbasis Kebangsaan (Surabaya, STAIN Salatiga Press, 2007.

Subagja,Soleh. Pendekatan Multikultural dalam Pendidikan Agama Islam. Malang, 2008.

Tobroni dkk. Pendidikan Kewarganegaraan Demokrasi, HAM, Civil Society, dan Multikulturalisme.Yogyakarta, PuSaPoM. 2007.

Wahid, Abdurrahman dkk. Quo Vadis Pendidikan Islam Pembacaan Realitas Pendidikan Islam, Sosial dan Keagamaan. Malang, UIN Malang Press, 2006.

Zakiyuddin Baidhawy. Membangun Harmoni dan Perdamaian Melalui Pendidikan Agama Berwawasan Multikultural. Jakarta, Departemen Agama, 2008. 